\title{
Violence and Bullying Incidents Reported by School Counselors: The Efficacy of Counselors and Preventive and Interventional Approaches
}

\author{
Zeynep Deniz Yondem \\ Abant Izzet Baysal University, Faculty of Education \\ Departmant of Counseling Psychology and Guidance, Bolu TURKEY
}

doi: 10.19044/esj.2016.v12n28p77 URL:http://dx.doi.org/10.19044/esj.2016.v12n28p77

\begin{abstract}
This study aims to determine the frequency of violence and bullying reported by Turkish school counselors and examines their perceived efficacy and preventive and interventional approaches using a qualitative/quantitative mixed method. Counselors reported the high frequency of different violent incidents (occurring between students, inflicted by families and inflicted by teachers) as recorded or in particular non-recorded. The frequency of family violence is higher in middle schools than high schools. All bullying frequency sub-types were high, physical bullying especially so. The frequency of physical, verbal and sexual bullying was significantly higher in middle schools. Trained and untrained counselors do not perceive efficacy as sufficient; they applied limited preventive and interventional studies, focusing on students rather than families or school personnel.
\end{abstract}

Keywords: Bullying, violence, school counselor, prevention

The concepts of school violence and bullying have become important issues in both research and the mass media. As many studies have shown, school violence and bullying are common problems in Turkey (Yöndem \& Totan, 2008; Yurtal \& Cenkseven, 2007; Ögel et al., 2006) and other countries (Owuamanam, 2015; Robers et al., 2013; Akiba, 2004; Unnever \& Cornell, 2003; Rigby, 2002; Wolke et al., 2001; Smith \& Brain, 2000; McDougall, 1999). The concept of bullying, first defined by Olweus (1994), refers to physically or psychologically harmful behaviours among peers in the context of a power imbalance. Some studies emphasise the different characteristics of violence and bullying (Ttofi \& Farrington, 2011); other studies consider bullying to be a type of violence or aggression (Miller \& Lynam, 2006; Smith \& Brain, 2000). This study uses the concepts of violence and bullying based on the assessment of teacher and family 
violence that has been assessed in current research. The term 'school violence' is more familiar then 'bullying' in developing countries such as Turkey.

Early published research on school bullying has largely focused on describing these phenomena, their prevalence and some of the personal or demographical characteristics of the students involved. Studies have shown that both bullies and victims are affected negatively in the long and short term (Baly et al., 2014; Skinner et al., 2014; Bender \& Lösel, 2011; Ttofi \& Farrington, 2011), and both tend to experience anti-social behaviours, depression, social anxiety, suicidal feelings, low self-esteem, school absences and academic problems. Additionally, such events affect the school climate and hinder school functions (K1zmaz, 2006; Whitted \& Dupper, 2005). Previous studies have compared students of different school grades to achieve a better understanding of these phenomena. In particular, comparative studies have shown that in general school violence and bullying incidents increase and peak during early adolescence (middle school years) and decrease during high school (Chen and Astor, 2009). However, other studies have shown that the prevalence of different sub-types of bullying may vary as a function of student age, with physical and cyberbullying declining and verbal bullying remaining higher in high school (Williams \& Guerra, 2007).

Theoretical explanations of this international problem have proposed that school violence and bullying cannot be explained by students’ personal characteristics alone. Merrell et al. (2008) stated that a common set of demographic, environmental, interpersonal and intrapersonal factors, including family factors such as poor parental role-modeling or ineffective discipline methods, have been associated with the etiology of school violence and bullying behaviours. Recently, some studies have stressed the supportive role of 'bullying culture' on bullying behaviours and the complex nature of school violence and bullying in a broader perspective (Unnever \& Cornell, 2003; Cowie \& Olafsson, 2000). In this context, Bronfenbrenner's socio-ecological approach, used to explain school violence and bullying issues, assumes that these issues can be related to large-scale factors such as school climate, teacher-student relationships, families, and social and cultural environments (Robers et al., 2013; Y1ldız \& Sümer, 2010; Craig \& Pepler, 2007; Unnever \& Cornell, 2003; Cowie \& Olafsson, 2000). In particular, the relationships between students and adults (including teachers and parents) strongly influence violence and bullying behaviours. Children and adolescents learn how to express feelings, such as anger and aggression, from adults; therefore, teachers and parents are role models who play a major part in promoting violence and bullying behaviours (Skinner et al., 2014; Espelage \& Swearer, 2010). In this respect, one part of this study focuses on 
violent behaviour as a part of the family-teacher-student triangle, a concept that has not yet been widely examined in the literature. Family violence and related topics (i.e., domestic violence, child abuse, partner abuse) are highly studied topics that feature heavily in the literature, but there are no reliable statistics about their prevalence because of the culturally accepted characteristics that are a normal part of family life and which must be keep secret among family members. However, one national survey of American families concludes that 50\% percent of men frequently assaulted their wives and also abused their children (Wallace \&Roberson, 2015). In Turkey, Vahip and Doğanavşargil (2006) reported that 63\% of female psychiatric outpatients had been physically abused in their homes during childhood, and $51 \%$ reported that they had also physically abused their children. A national survey of women revealed that $26-57 \%$ reported that they experienced physical violence in their marriage and usually their children witnessed the acts (Bayındir, 2010). There was a common acceptance of teachers using corporal punishment and physical violence as a traditional discipline method, despite some legal prohibitions, although there are limited studies and statistics on this topic. One recent archival survey (Bulut, 2008) showed that there were 172 newspaper and/or television articles in Turkey related to violence from teachers towards their students during the five-year period from 2000 to 2006.

In the related literature, the rate of school violence and bullying incidents has been largely estimated by surveying students. Several studies have examined the responses of teachers (Marshall et al., 2009; Bauman \& Del Rio, 2006; Yoon, 2004) to school violence and bullying. However, only limited attention has been paid to school counselors, the very individuals who are expected to prepare and organise comprehensive preventive and interventional programs depending on their professional responsibilities. Some of the recent literature focusing on school counselors revealed that a higher level of efficacy in addressing the concept of bullying is linked to counselors' intervention performance (Charlton, 2009) and that training related to handling bullying increases counselors' sensitivity to the issue (Jacobsen \& Bauman, 2007). Jacobsen and Bauman (2007) also noted that, according to school counselors, the actual number of incidents of bullying was higher than the figure reported.

Beginning with the Olweus Bullying Prevention Program in Norway, a number of anti-bullying programs have been implemented in many countries, and legislation has been passed to prevent and reduce school violence (Garrett, 2003). Anti-bullying school programs include awareness campaigns, surveys, strengthened discipline and sanctions, attempts to improve students' social skills, in-service training for school personnel and more comprehensive school-wide or community programs (Garrett, 2003). A 
range of comprehensive meta-analytic reviews in the recent literature has assessed the effectiveness of anti-bullying programs, including school-wide programs. The results showed low or modest positive outcomes (Lee et al., 2013; Bowllan, 2011; Ttofi \& Farrington, 2011; Merrell et al., 2008; Ferguson et al., 2007).

Turkish authorities have set their focus on this international concern of preventing school violence and bullying. One comprehensive action plan framework entitled the "Preventing and Reducing Violence in Educational Settings Action Plan" was prepared and announced to schools by the Ministry of National Education (MEB, 2009) to raise awareness of this issue. Based on the framework of a systemic-ecological perspective, this action plan includes many dimensions, such as the school environment, students, teachers, administrators and families. In this plan, school counselors are allocated considerable responsibility for preparing and implementing a course of action for schools. The effect of implementing such activities in a school has not yet been investigated. One of the studies conducted by the MEB reported that $90 \%$ of students involved in violent incidents at school were referred to school counseling services by school managers (MEB, 2007). Therefore, the only professionals who address violence and bullying incidents in schools are school counselors.

In light of the aforementioned research, this study aims to determine: (1) the frequency of different types of violent incidents (occurring between students, inflicted by families and inflicted by teachers) and their comparisons for the type of school depending on rates reported by school counselors; (2) the frequency of sub-types of bullying incidents (physical, verbal, relational, technological, sexual) and comparisons based on the type of school (primary, high schools, vocational high schools); (3) school counselors' training, perceived efficacy and educational needs related to this topic; and (4) preventive and interventional activities/approaches applied by school counselors to address violence and bullying issues two years after the announcement of the national action plan.

\section{Methods} method.

This descriptive study utilised a qualitative/quantitative mixed

\section{Participants}

The participants consisted of Turkish school counselors in state middle and high schools in a city located in northwestern Turkey. This study was approved by the Human Research Board of the corresponding authors' university and the Ministry of Education. The questionnaire was sent to school counselors via school web mail at the end of the 2012-2013 academic 
year. School counselors were assured confidentiality and that the results would be evaluated collectively. Sixty-four questionnaires were returned (44 females, 20 males), which corresponds to a return ratio of $80 \%$. All returned questionnaires were analysed for information related to school counselors' pre-service and/or in-service training, perceived professional efficacy and the need for training on violence and bullying issues. Thirty-four of these questionnaires (from 14 middle schools, 20 high schools counselors) were provided by school counselors who had worked for more than two years at the same school in order to determine the frequency of violence and bullying incidents and the preventive and interventional approaches that had been implemented. In 2011, the eight-year compulsory primary education system was replaced by the $4+4+4$ system (grades 1-4 elementary, grades 5-8 middle, grades 9-12 high school) in Turkey. Following this change, some school counselors continued to work at both elementary and middle schools, whereas some counselors were responsible only for elementary school counseling services. Appointing counselors to elementary schools is a new practice; therefore, the number of counselors working at that level is limited, and they were not included in this study.

\section{Instrument}

Both open and closed questions were included in the questionnaire. Questions on the following topics were used to collect quantitative data: gender, type of school, the number years of full-time service of school counselors, the years of service at the same school, previous counselor training on violence/bullying (yes/no), the kind of training received (written), perceived professional efficacy related to school violence and bullying (yes/no/partially) and whether they required any education or supervision (yes/no/partially). Two questions were used to determine the frequency of the types of violence and bullying incidents over the last two years (when the National Violence Action Plan was implemented). The first required the counselors to write the number of the different types of violent incidents using titles given by the researcher (between students, inflicted by family, and inflicted by teachers) as "recorded" (R) and "not recorded" (NR). Similarly, the second question focused on the number of the sub-types of bullying incidents, in which a general title and a short explanation provided by the researcher used terms in bullying literature: physical (hitting, beating, kicking, assault, etc.); verbal (threats, intimidation, coercion, name-calling, teasing, etc.); relational (rumors, gossip, social exclusion, shame); technological (using a phone, computer, text message, etc.) and sexual (abuse, harassment, rape). School counselors were also informed that they could estimate the number of NR incidents if they were uncertain. The term "recorded incidents" in this study refers to violence/bullying cases that were 
processed and recorded in school files by school counseling services or school management. However, because some cases were not recorded and one of the aims of this study was to investigate violence inflicted by parents and teachers (which typically was not recorded), the number of NR cases was added to reflect the actual violence/bullying rates. Furthermore, the school counselors' written personal statements were also added to the quantitative data. Finally, the qualitative data was collected with two open questions. For this purpose, the counselors were asked to explain preventive and interventional activities/approaches that they applied in their schools (written response). It was noted that the terms "prevention" and "intervention" were generally used interchangeably in the bullying literature. Conceptually, preventive approaches are more widespread; these approaches include all school students, personnel, families and other community systems and target improving awareness of these issues, changing the bullying culture and promoting a positive school environment. On the other hand, interventional approaches typically focus on selected/targeted students and their families who are involved in these behaviours in different ways (e.g., bully, victim, bystander).

\section{Data Analysis}

Regarding the first and second aims of the study to determine the frequency of the violence and bullying incidents and to compare according to the type of school, quantitative data was analysed descriptively using reported frequencies by 34 school counselors. Additionally, some written statements of school counselors were added to the results. For the analysis, first the written number of $\mathrm{R}$ and $\mathrm{NR}$ violence and bullying incidents reported by school counselors (during the last two academic years) were coded to SPSS 20 program and then recoded as two [1) none 2) 1 and more $(1+)$ ] or three [1) none; 2) 1 to 5; 3) 6 and more $(6+)$ ] categorical variables depending on the frequency of cells. Two counselors reported their estimate NR numbers as a range (for example, in relation to physical bullying between 20 and 30). In these cases, the midpoint of those numbers was considered an estimation number. For the analysis, the Chi-Square test was used to compare the frequencies of violence incidents (between students, inflicted by families, inflicted by teachers) according to the types of school (high school middle school). In a similar way, the same analysis was applied to compare the sub-types of bullying (physical, verbal, relational, technological, sexual) comparisons according to the types of school. All analyses applied both for reported R and total R+NR frequencies. In addition to the Chi-Square test, Fisher's Exact test was also applied because of small frequencies in some cells, and both the Pearson Chi-Square 'p' and Exact 'p' values were reported for all compared variables. Regarding the third aim of 
the study, all the returned questionnaires from 64 school counselors were considered, and the Chi-Square test was applied to compare trained and untrained ("not trained") school counselors according to perceived professional efficacy (2x3) (trained/not trained $x$ yes/no/partially). Additionally, school counselors’ education/supervision needs were reported. Regarding the final aim of the study, the qualitative research data of preventive and interventional activities/approaches was analyzed by identifying themes and sub-themes using a content-analysis method. Based on the collected data and the bullying literature, the preventive and interventional activities/approaches were categorized as school-based, family-oriented and student-oriented. Moreover, the frequency of each subtheme was examined to determine how often each activity occurred. Blank/incomplete questionnaires were reported as footnotes.

\section{Results}

The results relating to the first aim of the study showed that frequencies of different types of violence for two years (Table 1), in descending order, totaled $583(\mathrm{R}+\mathrm{NR})$ cases between students, 234 cases inflicted by families and 141 cases inflicted by teachers according to a report of 34 school counselors from middle and high schools. As shown in Table 1, NR frequencies were higher than $\mathrm{R}$ frequencies, with the high range of NR frequencies.

Table 1. Descriptives of Violence and Bullying Incidents Reported by the School Counselors

(Last 2 Academic Years) (from 34 School)

\begin{tabular}{cccccc} 
& & Mean & SD & Range & Sum \\
\hline Violence Between & $R$ & 9.59 & 13.90 & $0-59$ & 326 \\
Student & NR & 7.56 & 8.83 & $0-35$ & 257 \\
& Total & 17.15 & 16.40 & $1-64$ & 583 \\
\hline Violence & $R$ & .32 & 1.55 & $0-9$ & 11 \\
Families to Students & $N R$ & 6.56 & 22.10 & $0-125$ & 223 \\
& Total & 6.88 & 22.19 & $0-125$ & 234 \\
\hline Violence Teacher to & $R$ & 1.00 & 3.03 & $0-13$ & 34 \\
Students & NR & 3.15 & 8.26 & $0-45$ & 107 \\
& Total & 4.15 & 9.37 & $0-46$ & 141 \\
\hline Physical & $R$ & 6,38 & 12,04 & $0-66$ & 217 \\
Bullying & $N R$ & 11,85 & 42,53 & $0-250$ & 403 \\
& Total & 18.24 & 45.89 & $0-264$ & 620 \\
\hline Verbal & $R$ & 4,06 & 6,87 & $0-28$ & 138 \\
Bullying & $N R$ & 7,62 & 11,90 & $0-55$ & 259 \\
& Total & 11.68 & 13.22 & $0-55$ & 397 \\
\hline Relational & $R$ &, 41 & 1,40 & $0-7$ & 14 \\
Bullying & NR & 5,21 & 12,81 & $0-65$ & 177 \\
& Total & 5.62 & 12.79 & $0-65$ & 191 \\
\hline Technological & $R$ & 2,32 & 5,25 & $0-27$ & 79 \\
Bullying & NR & 2,97 & 4,39 & $0-15$ & 101
\end{tabular}


Bullying

$\begin{array}{cccc}\text { NR } & , 56 & 2,60 & 0-15 \\ \text { Total } & .88 & 2.71 & 0-15 \\ \text { Recorded } & \text { NR: Not Recorded; Total: R+NR } & \end{array}$

19

R: Recorded, NR: Not Recorded; Total: R+NR

The results revealed that there were no significant relationships between the types of violence and the types of school (high school, middle school) for R frequencies (Table 2): for student violence $(3 \times 2)\left(\chi^{2}(2)=.834\right.$, $\mathrm{p}=.659$; Fisher's Exact=.936, Exact $\mathrm{p}=.799)$, for inflicted by families $(2 \mathrm{x} 2)$ $\left(\chi^{2}(1)=.883, p=.347\right.$; Exact $\left.\mathrm{p}=.555\right)$ and for violence inflicted by teachers $(2 \times 2)\left(\chi^{2}(1)=.928, p=.335\right.$; Exact $\left.p=.410\right)$. When the same analysis was applied to the $\mathrm{R}+\mathrm{NR}$ frequencies (2x2), as seen in Table 2, while there were no significant relationships between student violence and the types of school $\left(\chi^{2}(1)=.731, p=.393\right.$; Fisher's Exact $=.467$, Exact $\left.p=.748\right)$ and violence inflicted by teachers $\left(\chi^{2}(1)=.064, p=.800\right.$; Exact $\left.p=1.000\right)$, there was a marginal significant $(\mathrm{p}<.05)$ relationship between violence inflicted by families and the types of school $\left(\chi^{2}(1)=4.371, p=.0307\right.$; Exact $\left.p=080\right)$ with the frequency for middle schools $29.4 \%$ higher than that for high schools $20.6 \%$. One of the school counselors' (female from middle school with ten years in full-time service) additional written explanation for family-tostudent violence was as follows: "Around $60-70 \%$ of the parents defend violence as a model at home, outside, in social life, at work, in traffic, etc. and regard the children's use of violence, cursing and slang as normal. In my interviews with parents, this topic is brought to the agenda, and the parents' approach astonished me.”

Table 2. Chi-Square Analysis Results for the Types of Violence and the Types of School Comparisons (for $\mathrm{R}+\mathrm{NR}$ frequencies)

\begin{tabular}{|c|c|c|c|c|c|c|c|}
\hline $\begin{array}{l}\text { Types of } \\
\text { Violence }\end{array}$ & Category & $\begin{array}{c}\text { High } \\
\text { School } \\
(\mathrm{n}=20) \\
\mathrm{f}(\%)\end{array}$ & $\begin{array}{r}\text { Middle } \\
\text { School } \\
(\mathrm{n}=14) \\
\mathrm{f}(\%)\end{array}$ & $\begin{array}{r}\text { Total } \\
(n=34) \\
\text { f (\%) }\end{array}$ & $\chi^{2}$ & $\mathrm{df}$ & $\begin{array}{c}\mathrm{p} \\
\text { Exact } \mathrm{p}\end{array}$ \\
\hline \multirow{3}{*}{$\begin{array}{l}\text { Between } \\
\text { Students }\end{array}$} & $1-5$ & 7 (20.6) & $3(8.8)$ & $10(29.4)$ & \multirow[t]{3}{*}{.731} & \multirow[t]{3}{*}{1} & .393 \\
\hline & & & & & & & .467 \\
\hline & $6+$ & $13(38.2)$ & $11(32.4)$ & $24(70.6)$ & & & \\
\hline \multirow{2}{*}{$\begin{array}{l}\text { Family to } \\
\text { Students }\end{array}$} & None & $13(38,2)$ & 4 (11.8) & $17(50,0)$ & \multirow[t]{2}{*}{4,371} & \multirow[t]{2}{*}{1} & ,037* \\
\hline & $1+$ & $7(20,6)$ & $10(29,4)$ & $17(50,0)$ & & & \\
\hline \multirow{2}{*}{$\begin{array}{l}\text { Teacher to } \\
\text { Students }\end{array}$} & None & 12 (35.3) & 9 (26.5) & 21 (61.8) & \multirow[t]{2}{*}{.064} & \multirow[t]{2}{*}{1} & \multirow{2}{*}{$\begin{array}{c}.800 \\
1.000\end{array}$} \\
\hline & $1+$ & $8(23.5)$ & 5 (14.7) & $13(38.2)$ & & & \\
\hline
\end{tabular}

${ }^{*} \mathrm{p}<.05 ; 1-5: 1$ to $5 ; 1+: 1$ and more; $6+: 6$ and more

Results relating to the second aim of the study showed that the frequencies of the sub-types of bullying incidents (Table 1) were as follows: 620 physical, 397 verbal, 191 relational, 180 technological and 30 sexual for total $\mathrm{R}+\mathrm{NR}$ frequencies. The results of the sub-types of bullying and the 
types of school (high school, middle school) comparisons revealed that there were only marginally significant relationships for sexual $(2 \times 2)\left(\chi^{2}(1)=5.346\right.$, $\mathrm{p}=.021$; Exact $\mathrm{p}=.061)$ but no significant relationships for physical $(3 \times 2)\left[\left(\chi^{2}\right.\right.$ $(2)=1.222, p=.543$; Fisher's Exact=1.235, Exact $p=.678)$, verbal $(3 \times 2)\left(\chi^{2}\right.$ $(2)=.318, p=.853$; Fisher's Exact $=.398$, Exact $p=1.00)$; relational $(2 \times 2)\left(\chi^{2}\right.$ $(1)=.146, p=.703$; Exact $p=1.00)$; technological $(2 \times 2)\left(\chi^{2}(1)=.169, p=.681\right.$; Exact $\mathrm{p}=.738$ ) for the frequencies of $\mathrm{R}$ incidents. Additionally, $\mathrm{R}+\mathrm{NR}$ frequency results showed that there were significant $(\mathrm{p}<.05)$ relationships between frequencies of physical bullying $(3 \times 2)\left[\left(\chi^{2}(2)=6.491, p=.039\right.\right.$; Fisher's Exact $=6.422$, Exact $p=.047)$, verbal bullying $\left[\left(\chi^{2}(2)=9.590, p=.008\right.\right.$; Fisher's Exact=9.104, Exact $\mathrm{p}=.012)$; and sexual bullying $(2 \times 2)\left(\chi^{2}\right.$ $(1)=7.219, p=.007$; Exact $p=.012$ ) and the type of school, with middle school frequencies higher than high school frequencies, as can be seen in Table 3 . However, there were no significant relationships between relational bullying $(2 \times 2)\left(\chi^{2}(1)=.000, p=1.000\right.$; Exact $\left.\mathrm{p}=1.000\right)$, and technological bullying $(2 \times 2)\left(\chi^{2}(1)=928, p=.335\right.$; Exact $\left.p=.410\right)$ and the types of school according to $\mathrm{R}+\mathrm{NR}$ frequencies.

Table 3. Chi-Square Analysis Results for the Types of Violence and the Types of School Comparisons (for $\mathrm{R}+\mathrm{NR}$ frequencies)

${ }^{*} \mathrm{p}<.05$; $1-5: 1$ to $5 ; 1+: 1$ and more; $6+: 6$ and more

\begin{tabular}{|c|c|c|c|c|c|c|c|c|}
\hline \multirow[b]{2}{*}{$\begin{array}{l}\text { Types of } \\
\text { Bullying }\end{array}$} & \multirow[b]{2}{*}{ Categories } & $\begin{array}{c}\text { High } \\
\text { School } \\
(n=20)\end{array}$ & $\begin{array}{l}\text { Middle } \\
\text { School } \\
(n=14)\end{array}$ & $\begin{array}{l}\text { Total } \\
(\mathrm{n}=34)\end{array}$ & \multirow{2}{*}{\multicolumn{2}{|c|}{$\begin{array}{c}\text { Fisher's } \\
\text { Exact } \\
\text { Test }\end{array}$}} & \multirow[b]{2}{*}{$\mathrm{df}$} & \multirow[b]{2}{*}{$\begin{array}{c}p \\
\text { Exact } \\
p\end{array}$} \\
\hline & & f (\%) & f (\%) & f (\%) & & & & \\
\hline \multirow[t]{3}{*}{ Physical } & none & $6(17.6)$ & $0(0.0)$ & $6(17.6)$ & \multirow[t]{3}{*}{6.491} & \multirow[t]{3}{*}{6.422} & \multirow[t]{3}{*}{2} & $\begin{array}{l}.039 * \\
0.47 *\end{array}$ \\
\hline & $1-5$ & $7(20,6)$ & $\begin{array}{c}4 \\
(11,8)\end{array}$ & $11(32,4)$ & & & & \\
\hline & $6+$ & $7(20,6)$ & $\begin{array}{c}10 \\
(29,4)\end{array}$ & $17(50,0)$ & & & & \\
\hline \multirow[t]{3}{*}{ Verbal } & none & $7(20,6)$ & $1(2,9)$ & $8(23,5)$ & \multirow[t]{3}{*}{9,590} & \multirow[t]{3}{*}{9,104} & \multirow[t]{3}{*}{2} & ,008* \\
\hline & $1-5$ & $8(23,5)$ & $2(5.9)$ & $10(29,4)$ & & & & ,012* \\
\hline & $6+$ & $5(14,7)$ & $\begin{array}{c}11 \\
(32,4)\end{array}$ & $16(47,1)$ & & & & \\
\hline \multirow[t]{2}{*}{ Sexual } & none & $19(55,9)$ & $8(23,5)$ & $27(79,4)$ & \multirow[t]{2}{*}{7,219} & \multirow[t]{2}{*}{--} & \multirow[t]{2}{*}{1} & $\begin{array}{l}, 007^{*} \\
, 012^{*}\end{array}$ \\
\hline & $1+$ & $1(2,9)$ & $6(17,6)$ & $7(20,6)$ & & & & \\
\hline \multirow{2}{*}{$\begin{array}{l}\text { Sexual } \\
\text { (for R) }\end{array}$} & none & $19(55,9)$ & $9(26,5)$ & $28(82,4)$ & \multirow[t]{2}{*}{5,346} & \multirow[t]{2}{*}{-} & \multirow[t]{2}{*}{1} & ,021* \\
\hline & $1+$ & $1(2,9)$ & $5(14,7)$ & $6(17,6)$ & & & & .061 \\
\hline
\end{tabular}


Of the total number of 64 counselors who were the focus of the third aim of the study, $51(79.7 \%)$ reported that they had received no training on the topic of school violence and/or bullying. Only nine counselors stated that they had received in-service training on school violence, bullying and peer mediation issues. Four counselors stated they had listened to a student presentation as part of a seminar course during their undergraduate education. Regarding the counselors' perceived professional efficacy in addressing violence and bullying, only 6 of the 64 counselors $(9.4 \%)$ stated that they perceived their professional efficacy to be sufficient, 37 (57.8\%) perceived partial sufficiency and 21 (32.8\%) perceived insufficiency. Only two of the counselors (3.2\%) stated that they did not need training on bullying compared with 62 counselors (96.8\%) who stated otherwise. Additionally, Chi-Square test results revealed that there were no relations between trained and untrained school counselors frequencies and perceived efficacy $(2 \times 3)$ on this issue $\left(\chi^{2}(2)=1.913, p=.384\right.$; Fisher's Exact $=1.892$, Exact $\mathrm{p}=.458$ ). One of the school counselors (female from a middle school with 18 years full-time service) explained, "I received in-service education on violence and bullying from the Ministry of Education. But I don't think these kinds of courses are effective for school counselors, so they usually stay at an informative level."

Table 4 School Counselors’ Preventive Approaches Against School Violence and Bullying

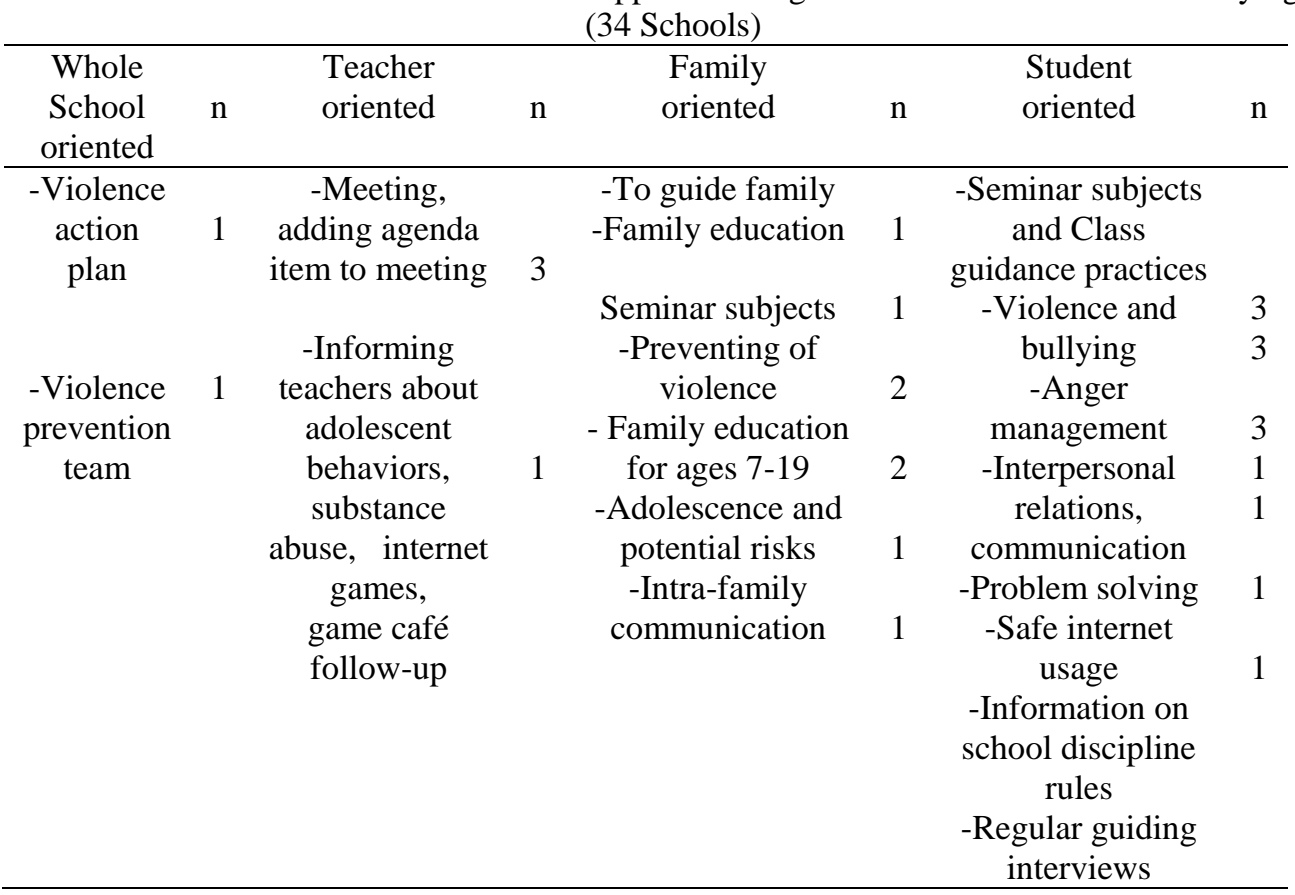

Blank: 9 
Tables 4 and 5 summarize the final aim of the study, i.e. the content analysis. Table 4 lists the preventive studies applied by school counselors. The most frequently used preventive method was informing students via class-based guidance activities, followed by family education. However, the results showed that nine school counselors (26.5\%) did not use any of these activities to address school violence and bullying in their schools. Moreover, violence action plans and violence prevention teams, both school-based activities, were seldom utilised.

Table 5. School Counselors' Interventional Approaches Against School Violence and Bullying (34 School)

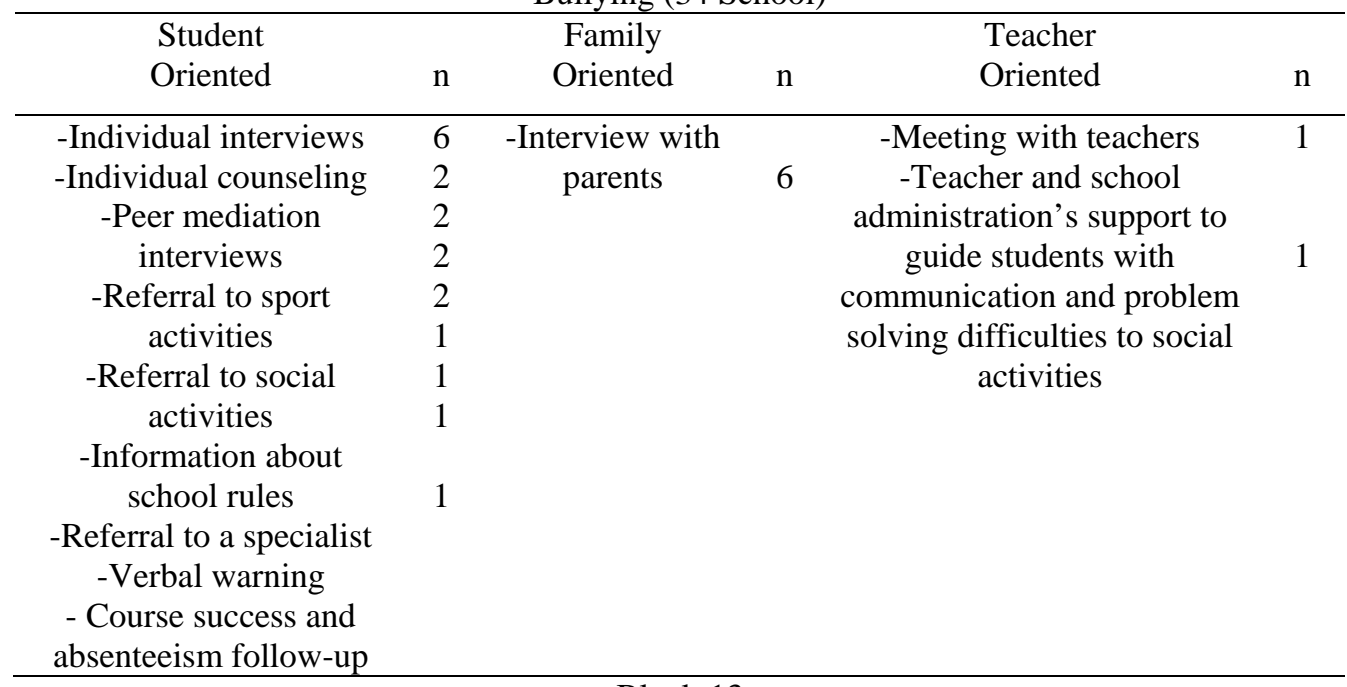

Blank:13

In terms of the counselors' interventional approaches to addressing school violence and bullying (Table 5), the results indicated that 13 counselors (38.2\%) did not intervene at all. When the content of the interventions was analysed, the focus appeared to be primarily on students. The most common student-oriented intervention was individual interviews. Other types of interventions included peer mediation with class members or friends, referral to sports or social activities, providing information on school rules and referral to a specialist. Among the family-oriented interventions, interviews with the family were the most common strategy, but this approach was used only to a limited extent by counselors.

Another interesting finding is revealed in the following statement from one of the school counselors (female from a middle school with 19 years full-time service who had attended some workshops on school violence and bullying issues): "Intervention was not useful, so I did not perform it." Notably, it was observed that several counselors had difficulties 
distinguishing preventive and interventional approaches, and they occasionally even considered regular guidance practices to be interventions.

\section{Discussion}

The results of this study indicate that high frequencies of violence between students and bullying reported by school counselors are consistent with those of prior studies indicating that school violence and bullying is prevalent in Turkish schools according to student surveying (Yarpuzlu et al., 2010; Kepenekci \& Cinkır, 2006; Ogel et al., 2006). The results of the current study also show that a high number of violence and bullying incidences were not recorded by the school managers or counselors. This issue was also pointed out in Jacobsen and Bauman's (2007) studies with school counselors. These off-the-record incidents may be related to school management or counseling services, or students may perceive this kind of aggressive behaviour as acceptable and may underestimate this serious problem. These unreported incidents may be quite misleading and pose a serious problem for researchers and scholars in the field.

The current study results indicated that, in addition to the high frequency of violence between students (recorded or not recorded), the incidence of families' or teachers' violence to students is also prevalent. The frequency of the violence incidence inflicted by families are respectively higher in middle schools on the basis of school counselors' reports. This is not usually surveyed and recorded aspect of violence and bullying in school violence and bullying literature despite the wide range of theoretical explanations which addressing it as an important possible underlying factors. In Turkey, a limited number of previous studies pointed to the maladaptive parental behaviour, inappropriate discipline methods used by parents (Cumhuriyet Gazetesi, 2009) and the effects of teachers’ poor qualifications, attitudes and behaviour (Celebi \& Asan, 2009; Piskin, 2006) on school violence and bullying issues. This issues were only discussed at a theoretical level. Similarly, Pinherio (2006) reveals the universality of violence against children and youth at home and in schools. Some of the theoretical explanations of school violence and bullying, including the social psychological model, the social learning theory and the culture of violence theory, strongly point to adult violence as an important underlying factor for school violence and bullying. These models also point to the cyclical aspect of violence and assume violence to be a learned behavior that is passed on to new generations as culturally accepted behaviour (Wallace \&Roberson, 2015). In this context, the ecological perspectives of school violence suggest that prevention approaches must include demographic characteristics of students, home environment, the school culture and also out-of-school variables in a broader perspective. 
The results of the current study showed almost all sub-types of bullying frequencies were high; amongst these, physical bullying is more often reported by school counselors than the other forms of bullying. The higher frequencies of physical bullying may be related to the current study participants' low perceived efficacy regarding school violence and bullying issues. The results of Jacobsen and Bauman's (2007) study also support the current findings. They found that counselors with anti-bullying training rated relational bullying as more serious than counselors without such training. Also, Bauman and Del Rio (2006) reported that relational bullying was seen as less serious than physical or verbal bullying by pre-service teachers. It can be concluded that, for untrained individuals and school counselors, physical bullying is attracting more attention as a form of aggressive behaviour than the other types of bullying.

It is commonly mentioned that bullying happens to nearly all schoolaged children and youngsters in general. Some previous studies point out that the beginning of aggressive and harassing behavior typically occurs at the end of primary school and during the transition to middle school (Pellegrini, 2002; Sanchez, Roberson et al., 2001). Furthermore, Chen and Astor (2009) indicate that it is more prevalent in middle school than high school. There were also some limited and controversial results for the sub-types of bullying and comparisons of the type of schools. The results of the current study show that physical, verbal and sexual bullying frequencies are higher in middle schools. Some of the recent bullying literature shows that physical and cyber bullying peaks in middle school and decreases in high school and that verbal and relational bullying increases in high school (Wang et al., 2009; Williams \& Guerra, 2007). On the other hand, Espelage, Basile and Hamburger (2012) draw attention to sexual harassment as an ignored form of bullying in bullying literature. Furthermore, they note that efforts towards prevention are often ignored. These authors stressed that sexual harassment may overlap and correlate with the other forms of bullying, especially with verbal bullying in middle school ages. It can be concluded, therefore, that there is a need for further studies on comparisons of different forms of bullying and grade levels for more specific information on preventive tactics.

The results of this study showed that, among the study participants, most school counselors do not have training and those who are trained still reported lower levels of perceived professional efficacy on this topic. School counselors do not regard themselves as professionally competent to handle these issues, despite their role in prevention being so critical and crucial. Charlton (2009) found that counselors' efficacy is linked with intervention performance. These results were also supported by a recent study (Uzbas, 2009) which found that most Turkish school counselors have low perceived efficacy and they expect to learn short and solution-focused approaches on 
school violence and bullying issues. Even two years after the announcement of a national action plan, preventive and interventional efforts organized by school counselors are very limited. Some school counselors reported that they did not promote any activities for school violence or bullying, although this result might be associated with counselors who were not aware of any preventive or interventional activities. Furthermore, this report might be an indication that personnel are uninformed regarding a very serious problem despite the presence of a national announcement. Similarly, none of the counselors reported that they used any familiar or packaged anti-bullying programs, despite the fact that a wide range of such programs is listed in the bullying literature (Lund et al., 2012; Garrett, 2003). Additionally, results showed that school counselors are more likely to focus on students by providing seminars and informing them via class-based guidance activities as a prevention method. Interviewing students and their families was another applied intervention used by school counselors, which is also listed as a commonly applied intervention in bullying literature (Lund et al., 2012). However, activities/approaches towards teachers and families and addressing the whole-school context were very limited. In contrast, the literature emphasises that school-wide and community-oriented approaches are more effective (Garrett, 2003) and that many schools and states have continued to improve such models following the launch of the Olweus Bullying Prevention Program in the 1970s. However, such efforts are still limited and mostly student-oriented in Turkey. No evidence-based or culturally adopted anti-bullying programs have been examined by scholars due to a lack of these adapted programs in Turkey. Only a few descriptive study results reported the prevalence and seriousness of these school problems.

School counselors play a critical role in preventing and intervening in bullying. They can survey the prevalence of bullying, inform and consult school personnel and parents, teach and counsel students about managing aggressive behaviours, improve social skills, teach conflict resolution and increase prosocial behaviour (www.stopbullying.gov). Therefore, improving the professional knowledge and skills of counselors may improve the quality of anti-bullying school programs.

\section{Limitations}

One limitation of this study is the relatively small number of participants. Additionally, the school counselors were all selected from a particular area, and the possibility exists that the frequency and type of violence and the form of bullying might differ among various school atmospheres and sociocultural surroundings. Another major limitation of this study was the subjectivity of the 'not recorded-NR' rate of incidents, which depends on school counselors' guesses and estimated numbers. Therefore, 
these limitations must be taken into consideration when interpreting the findings of the study.

\section{Conclusion}

The rates and frequencies of school violence and bullying incidents may change given the various sociocultural surrounding factors of the school, students and sensitivity of school personnel. In Turkey, in spite of the high frequency of this serious school problem, indicated by recent studies and also supported by the current study, there were a limited number of preventive and interventional studies in school settings. Improving the professional efficiency of school counselors may improve the quality of prevention studies related to school violence and bullying issues. Additionally, there is a need for more structured and culturally adapted antibullying programs in Turkey, which combine out of school variables with an ecological framework.

Although there is a need for further supportive studies regarding family/parents and teachers' changeable role in different cultures on school violence and/or bullying issues, it can be concluded that family characteristics and cultural backgrounds may be one underlying factor for school violence or bullying between students in some cultures or multicultural school settings. However, violence or harassment at schools is essentially a school problem, as Craig and Pepler stated (2007). They further indicated that in some cultures prevention requires many participants including families, universities, non-governmental organizations, and judicial and legal legislations, along with the pioneering work of schools and school counselors.

\section{References:}

1. Akiba, M. (2004). Nature and correlates of ljime-bullying in Japanese middle school. Int J Educ Res, 41(3), 216-236.

2. Baly, M.W., Cornell, D.G. \& Lovegrove, P. (2014). A longitudinal investigation of self-and peer reports of bullying victimization across middle school. Psychol Sch.,51(3), 217-240.

3. Bauman, S. \& Del Rio, A. (2006). Preservice teachers' responses to bullying scenarios: Comparing phsical, verbal and relational bullying. Journal of Educational Psychology, 98(1), 219-231.

4. Bayındır, N. (2010). Aile içi şiddete karşı çocuğun gösterdiği tepkiler (The impact of violence in family lived). Mehmet Akif Ersoy Üniversitesi Sosyal Bilimler Enstitüsü Dergisi, 2(2), 1-9.

5. Bender, D. \& Lösel, F. (2011). Bullying at school as a predictor of delinquency, violence and other anti-social behaviour in adulthood. Crim Behav Ment Health, 21(2), 99-106. 
6. Bowllan, N.M. (2011). Implementation and evaluation of a comprehensive, school-wide bullying prevention program in an urban/suburban middle school. J Sch Health., 81(4), 167-173.

7. Bulut, S. (2008). Violence that emerges from teachers toward students: A quantitative investigation. Abant Izzet Baysal Universitesi Egitim Fakültesi Dergisi, 8(1),105-118.

8. Celebi, N. \& Asan, H.T. (2009). Ilkogretim ve lise ogrencilerine yonelik siddet ve tacizle ilgili bir arastırma (A study on violence and harrasment towards primary education and high school student's). Sakarya Universitesi Egitim Fakultesi Dergisi., 17, 130-155.

9. Charlton, A.L. (2009). School Counselors' Perceived Self-Efficacy for Addressing Bullying in the Elementary School Setting. Diss. Faculty of Virginia Polytechnic Institute and State University Rertrieved from: http://scholar.lib.vt.edu/theses/available/ etd04132009-102024/unrestricted/Charlton_AL_May_2009[1].pdf

10. Chen, J.K. \& Astor, R.A. (2009). The perpetrations of school violence in Taiwan: An analysis of gender, grade level and school type. School Psychology International, 30(6), 568-584.

11. Cowie, H. \& Olafsson, R. (2000). The role of peer support in helping the victims of bullying in a school with high levels of aggression. Sch Psychol Int., 21(1),79-95.

12. Craig, W.M. \& Pepler, D.J. (2007). Understanding bullying: From research to practice. Can Psychol., 48(2),86-93.

13. Cumhuriyet Gazetesi. (2009, May 17). Retrieved April 18, 2014 from http://www.cumhuriyet.com.tr/ haber/diger/62138/Okullar_siddet_yuvasi.html)

14. Espelage, D.L, Basile, K.C \& Hamburger, M.E. (2012). Bullying perpetrations and subsequent sexual violence perpetrations among middle school students. Journal of Adolescent Health, 50, 60-65.

15. Espelage, D.L. \& Swearer, S.M. (2010). A social-ecological model for bullying prevention and intervention: Understanding the impact of adults in the social ecology of youngsters. In . SR Jimerson, SM Swearer \& DL Espelage (Eds.), Handbook of Bullying in Schools: An International Perspective (61-72). New York: Routledge

16. Ferguson, C.J., San Miguel, C., Kilburn, J.C. \& Sanchez, P. (2007). The Effectiveness of School-Based Anti-Bullying Programs A MetaAnalytic Review. Crim Justice Rev., 32(4), 401-414.

17. Garrett, A.G. (2003). Bullying in American Schools: Causes, Preventions, Interventions. NC: McFarland \& Company

18. Jacobsen, K.E. \& Bauman, S. (2007). Bullying in schools: School counselors' responses to three types of bullying incidents. Professional School Counseling.,11(1), 1-9. 
19. Kepenekci, Y.K. \& Cinkır, S. (2006). Bullying among Turkish high school students. Child Abuse \& Neglect,30(2), 193-204.

20. Kızmaz, Z. (2006). Okullardaki siddet davranısının kaynakları uzerine kuramsal bir yaklasim ( A theoretical approach to the roots of violence behaviors at schools). Cumhuriyet Universitesi Sosyal Bilimler Dergisi,30(11), 47-70.

21. Lee, S., Kim, C.J. \& Kim, D.H. (2013). A meta-analysis of the effect of school-based anti-bullying programs. J Child Health Care. DOİ: 10.1177/1367493513503581.

22. Lund, E.M., Blake, J.J., Ewing, H.K. \& Banks, C.S. (2012). School counselors' and school psychologists' bullying prevention and intervention strategies: A look into real-world practices. Journal of School Violence, 11(3), 246-265.

23. Marshall, M.L., Varjos, K., Meyers, J., Graybill, E.C. \& Skoczylas, R.B. (2009). Teacher responses to bullying: Reports from front line. Journal of School Violence, 8(2), 136-158.

24. McDougall, L. (1999). A study of bullying in further education. Pastor Care Educ.,17(2), 31-37.

25. MEB. (2009). Egitim ortamlarında siddetin onlenmesi ve azaltılmasi strateji ve eylem planı (Ministry of National Education, Preventing and reducing strategies and action plan for violence in educational setting) Retrieved October 2, 2014, from http://mevzuat.meb.gov.tr/html/2009_9.html

26. MEB. (2007). Ortaogretim okullarında gorevli yoneticilerin siddet konusundaki bilgi ve becerilerine iliskin mevcut durum analizi (Ministry of National Education, An analysis of school managers' knowledge and skills related with school violence Ankara, 2007. Retrieved October 4, 2014, from http://yegitek.meb.gov.tr/tamamlanan/siddet_ arastirmasi_yonetici.pdf

27. Merrell, K.W., Gueldner, B.A., Ross, S.W. \& Isava, D.M. (2008). How effective are school bullying intervention programs? A metaanalysis of intervention research. Sch Psychol Q.,23(1),26-42.

28. Miller, J.D., Lynam, D.R. (2006). Reactive and proactive aggression: Similarities and differences. Pers Individ Dif.,41(8), 1469-1480.

29. Ogel, K., Tar1, I. \& Eke, C.Y. (2006). Okullarda Suc ve Siddeti Onleme (Crime and violence prevention in schools). Vol 17. Istanbul: Yeniden Yayınları

30. Olweus, D. (1994). Bullying at School. In.LR Huesmann (Eds.), Aggressive Behavior. (97-130). US: Springer. 
31. Owuamanam, D.O. (2015). Prevalence of bullying among secondary school students in Ondo state, Nigeria. European Scientific Journal,11(20), 326-333.

32. Pellegrini, A.D. (2002). Bullying, victimization, and sexual harassment during the transition to middle school. Educational Psychologist, 37(3),151-163.

33. Piskin, M. (2006). Okul siddeti: Tanımı, yaygınlıgı ve onleme stratejileri (School violence: definition, prevalance and prevention strategies). Kamuda Sosyal Politika Dergisi,1(2),45-62.

34. Rigby, K. (2002). New perspectives on bullying. London: Jessica Kingsley Publishers

35. Robers, S., Kemp, J., Truman, J. \& Snyder, T.D. (2013). Indicators of school crime and safety: 2012. NCES 2013-036/NCJ 241446. Retrieved October 4, 2014, from http://nces.ed.gov/pubs2013/2013036.pdf

36. Sanchez, E., Robertson, T.R., Lewis, C.M., Rosenbluth, B., Bohman, T. \& Casey, D.M. (2001). Preventing bullying and sexual harassment in elementary schools: The Expect Respect Model. Journal of Emotional Abuse, 2(2/3), 157-180.

37. Skinner, A.T, Babinski, L.M. \& Gifford, E.J. (2014). Teachers' expectations and self-efficiacy for working with bullies and victims. Psychol Sch.,51(1),72-84.

38. Smith, P.K. \& Brain, P. (2000). Bullying in schools: Lessons from two decades of research. Aggress Behav., 26(1), 1-9.

39. Ttofi, M.M. \& Farrington, D.P. (2011). Effectiveness of school-based programs to reduce bullying: A systematic and meta-analytic review. J Exp Criminol., 7(1),27-56.

40. Unnever, J.D. \& Cornell, D.G. (2003). The culture of bullying in middle school. J Sch Violence., 2(2),5-27.

41. Uzbas, A. (2009). The evaluation of school counselors' opinion about school violence and aggression. Mehmet Akif Ersoy Üniversitesi Eğitim Fakültesi Dergisi, 9(18), 90-110.

42. Vahip, I. \& Doganavsargil, Ö. (2006). Domestic violence and female patients. Türk Psikiyatri Dergisi, 17(2), 107-114.

43. Wallace, P.H. \& Roberson, C. (2015). Family Violence: Legal, Medical and Social Perspectives(seventh eds.), NY: Routledge

44. Wang, J., Iannotti, R.J. \& Nansel, T.R. (2009). School bullying among US adolescents: Physical, relational and cyber. J Adolesc Health, 45(4), 368-375.

45. Whitted, K.S. \& Dupper, D.R. (2005). Best practices for preventing or reducing bullying in schools. Child Sch., 27(3),167-175. 
46. Williams, K.R. \& Guerra, N.G. (2007). Prevalence and predictors of internet bullying. J Adolesc Health, 41(6), 14-21.

47. Wolke, D., Woods, S., Stanford, K. \& Schulz, H. (2001). Bullying and victimization of primary school children in England and Germany: Prevalence and school factors. Br J Psychol., 92(4),673696.

48. www.stopbullying.gov/prevention/training_center/hrsa_guide_mental _health_professionals_508pdf. Retrived January 23, 2016.

49. Yarpuzlu, A., Baran, G.K. \& Kilıc, E. (2010). An Investigation of School Violence and School Safety Based on Opinions of High School Students and Teachers in Ankara, Turkey. Ankara Universitesi Tıp Fakültesi Mecmuasi, 63(4), 101-105. DOI: 10.1501/Tipfak_000000771

50. Yıldı,, E.C. \& Sumer, Z.H. (2010). Saldırgan davranıslarını yordamada cevresel risk, cevresel guvenlik ve okul iklimi algısı ( Perceived neigborhood risk, neigborhood safety and school climate in predicting aggressive behaviors). Turk Psikolojik Danısma ve Rehberlik Dergisi., 4(34),161-173.

51. Yoon, J.S. (2004). Predicting teacher intervention in bullying situations. Education \& Treatment of Children, 27(1), 37-45.

52. Yondem, Z.D. \& Totan, T. (2008). Ergenlerde zorbalik ve stresle basetme (Bullying and coping with stress in adolescents). Cukurova Univ Egit Fak Derg.,3(35), 28-37.

53. Yurtal, F. \& Cenkseven, F. (2007). Ilkogretim okullarında zorbalığın yaygınlıgı ve dogası (Prevalence and types of bullying at primary schools). Turk Psikolojik Danısma ve Rehberlik Dergisi.,3(28), 1-13. 